\title{
O ENSINO DE FILOSOFIA NAS PERSPECTIVAS INTER E TRANSDISCIPLINAR: A PROBLEMÁTICA DO CONHECIMENTO
}

\author{
Gilson Malta da Silva ${ }^{1}$ \\ Universidade Federal de São João del-Rei (UFSJ) \\ https://orcid.org/0000-0002-7566-0156
}

\begin{abstract}
RESUMO:
Este artigo tem por objetivo divulgar parte dos resultados de uma investigação sobre a organização de um ensino de filosofia proposto nas perspectivas inter e transdisciplinar. Tratou-se de averiguar como esse ensino estava sendo organizado numa determinada unidade educacional. Sendo assim, para investigar esse problema, realizou-se uma pesquisa descritiva de natureza qualitativa. $O$ percurso metodológico foi composto por investigação teórica e incursão a campo. A primeira etapa constituiuse de pesquisa bibliográfica e análise documental. A segunda consistiu em observar a organização do ensino em sala de aula. Como técnica de análise de dados utilizou-se a análise de conteúdo. As questões discutidas nesse artigo referem-se ao conjunto das aulas nas quais foi abordada a problemática do conhecimento. Concluiu-se que as características do ensino observado, no que se refere à problemática em questão, permitem considerá-lo uma multidisciplinaridade escolar "modesta".
\end{abstract}

PAlaVRas-ChaVE: Reforma do Ensino Médio. Ensino de filosofia. Interdisciplinaridade. Transdisciplinaridade.

\section{THE TEACHING OF PHILOSOPHY IN THE INTER AND TRANSDISCIPLINARY PERSPECTIVES: THE PROBLEM OF KNOWLEDGE}

\begin{abstract}
:
This article aims to disseminate part of the results of an investigation about the organization of a philosophy teaching proposed in the inter and transdisciplinary perspectives. It was a question of how this teaching was being organized in a particular educational unit. Thus, to investigate this problem, a qualitative descriptive research was carried out. The methodological course was constituted by theoretical investigation and incursion into the field. The first stage consisted of bibliographical research and documentary analysis. The second was to observe the organization of teaching in the classroom. The analysis of data was used as the data analysis technique. The issues discussed in this article refer to the set of classes in which the knowledge problem was addressed. It was concluded that the characteristics of the teaching observed, with respect to the problematic in question, allow to consider it a "modest" school multidisciplinarity.
\end{abstract}

KEYWORDS: High School Reform. Teaching philosophy. Interdisciplinarity. Transdisciplinarity.

1 Graduado em Filosofia e mestre em Processos Sócio-Educativos e Práticas Escolares pela Universidade Federal de São João del-Rei (UFSJ), Minas Gerais - Brasil. E-mail: fidalgogi@hotmail.com.

SILVA, Gilson Malta da. O ensino de filosofia nas perspectivas inter e transdisciplinar: a problemática do conhecimento. Griot : Revista de Filosofia, Amargosa, Bahia, v.16, n.2, p.398-422, dezembro/2017. 


\section{Considerações iniciais}

No final dos anos 90, presenciou-se uma reforma na educação básica. Dentre outras modificações, destaca-se a reorganização curricular para a etapa do ensino médio. Essa reorganização consiste num novo planejamento curricular que supere a tradicional organização por disciplinas isoladas. Esse modelo tradicional deveria ceder lugar a um processo permanente de integração e articulação dos conteúdos das disciplinas escolares num processo permanente de interdisciplinaridade, transdisciplinaridade e contextualização (BRASIL, 1999 a).

Zibas (2005) apresenta os vários fatores que justificaram a mencionada reforma. Dentre eles, destacam-se: intensificação das críticas a certos tipos de mediação docente caracterizadas pela transmissão de conteúdos enciclopédicos e descontextualizados, profundas mudanças sociais e a consequente necessidade de organizar uma educação científica que não estivesse atrelada ao formato conteúdista, expositivo e depositário. Isto posto, Brasil (1999a, p. 9), destaca que a organização curricular das unidades educacionais deve articular-se por "eixos básicos orientadores da seleção de conteúdos significativos, tendo em vista as competências e habilidades que se pretendem desenvolver no Ensino Médio" (Ibid., p. 16; itálico nosso)².

Nesse novo paradigma de reforma do ensino médio as disciplinas escolares passaram ser compreendidas como "recortes das áreas de conhecimento que representam, carregam sempre um grau de arbitrariedade e não esgotam isoladamente a realidade dos fatos físicos e sociais, devendo buscar entre si interações que permitam aos alunos a compreensão mais ampla da realidade" (BRASIL, 1999a, p. 103).

À vista disso, a política educacional brasileira (BRASIL, 2006), nãos só concretizou a reintrodução da filosofia como disciplina obrigatória no ensino médio, mas ainda destacou as potencialidades metadisciplinares desse saber no âmbito escolar. Desse modo, desde Brasil (1998) tem sido destacado o caráter interdisciplinar do ensino de filosofia e a necessidade de contextualizar os problemas nele abordados. Nessa perspectiva, Brasil (1999 b, p. 44) ressalta a pertinência de construir um ensino de filosofia que seja "o espaço por excelência para tematizar e explicitar os conceitos que permeiam todas as outras disciplinas [...] buscando suas raízes ou fundamentos e pressupostos" e elaborando "uma visão globalizante, interdisciplinar e mesmo transdisciplinar (metadisciplinar)" da realidade.

É nesse cenário que se insere a proposta do Colégio Nossa Senhora de Lourdes em construir um ensino de filosofia inter e transdisciplinar. O referido Colégio faz parte da rede privada de ensino e localiza-se na região central do município de Lavras, no Estado de Minas Gerais. Trata-se de uma instituição de orientação católica. Em fevereiro de 2012, visitei esse Colégio no intuito de solicitar à diretoria uma autorização para realizar a pesquisa. Concedida a autorização, na semana seguinte iniciei as observações em três turmas, respectivamente, do $1^{\circ}, 2^{\circ}$ e $3^{\circ}$ ano do ensino médio.

\footnotetext{
2 Para conhecimento de algumas críticas referentes a essa política curricular e ao modelo educacional caracterizado pelo desenvolvimento de competências e habilidades, conferir: Lopes (2004) e Zibas (2005).
}

SILVA, Gilson Malta da. O ensino de filosofia nas perspectivas inter e transdisciplinar: a problemática do conhecimento. Griot : Revista de Filosofia, Amargosa, Bahia, v.16, n.2, p.398-422, dezembro/2017. 


\section{Aspectos Metodológicos}

Na pesquisa bibliográfica, preliminarmente, buscou-se identificar as fontes bibliográficas que abordavam a problemática das metodologias de ligação dos saberes. De posse desse material, passou-se a leitura exploratória a fim de verificar em que medida a obra consultada interessava a pesquisa. Nessa etapa decidimos quais seriam os referenciais teóricos e quais obras constituiriam as demais referências. Em seguida, iniciou-se a leitura seletiva na qual determinamos o material bibliográfico que, de fato, seria utilizado na pesquisa. Os objetivos que norteava essa seleção consistiam em contextualizar e caracterizar as distintas metodologias de ligação dos saberes, nos âmbitos epistemológico e didático e aprofundar a compreensão a respeito dos referenciais teóricos. Ulteriormente, considerando o problema de pesquisa, fizemos a leitura analítica procurando ordenar, compreender e sumariar os dados e informações contidos nas fontes pesquisadas. Nessa fase, tomou-se os apontamentos das partes dos textos que se considerou principais e, assim, confeccionou-se as fichas de leitura e definiu-se as categorias analíticas, a saber: pluridisciplinaridade, multidisciplinaridade, interdisciplinaridade (âmbitos científicos e escolares) e transdisciplinaridade. Essas categorias foram "consideradas balizas para o conhecimento do objeto" - ensino de filosofia inter e transdisciplinar - "nos seus aspectos gerais", orientando os estudos bibliográficos, documentais e de campo (MINAYO, 1998, p. 94). Por fim, realizou-se a leitura interpretativa buscando relacionar os assuntos abordados pelos autores, nas distintas fontes, com o problema da pesquisa, a saber: como estava sendo organizado um ensino de filosofia inter e transdisciplinar.

Além disso, na análise documental, de início, buscou-se: descobrir as fontes primárias elaboradas nas reuniões mundiais sobre a as metodologias de ligação dos saberes; com destaque para o objetivo de melhor explicitar as características da Transdisciplinaridade ${ }^{3}$; os documentos governamentais sobre a reforma curricular do ensino médio e ensino de filosofia; o Proposto Político-Pedagógico do Colégio e os Planos Anuais do Curso de Filosofia para o $1^{\circ}, 2^{\circ}$ e $3^{\circ}$ ano do ensino médio; os materiais didáticos selecionados pelo docente para organização de sua mediação. Os objetivos foram: aprofundar o conhecimento sobre as diferentes metodologias de ligação dos saberes e melhor compreender os contextos que possibilitaram o surgimento de cada uma delas; ampliar a compreensão sobre a referida reforma curricular e sobre as características evidenciadas para o ensino de filosofia, principalmente sobre as relações entre o ensino de filosofia e as demais disciplinas escolares; conhecer os objetivos do Projeto Político-Pedagógico e dos Planos Anuais do Curso de Filosofia e averiguar quais foram os conteúdos priorizados pelo docente na construção do ensino de filosofia. Os mencionados objetivos foram concretizados por meio de outras leituras exploratória, seletiva, analítica, interpretativa e pelos fichamentos desses documentos primários.

Outrossim, a incursão a campo foi caracterizada pela observação de 62 aulas de filosofia do ensino médio, abrangendo o primeiro e o segundo semestre do ano de 2012 e perfazendo um total de 30 semanas de observações. Através da técnica da

\footnotetext{
${ }^{3}$ Colóquio de Veneza (1986); Congresso de Paris (1991); Congresso de Arrábida (1994); Congresso de Locarno (1997); Conferência de Zurique (2000)
} 
observação não participante coletou-se os dados referentes à concretização do ensino de filosofia em sala de aula. A opção pela escolha desse tipo de observação apóia-se na possibilidade do registro dos dados à medida que eles vão emergindo espontaneamente pelas interações entre os sujeitos da pesquisa no ambiente da observação; e, ainda permite reduzir as interferências de possíveis tendências seletivas do pesquisador em restringir a coleta de dados aos problemas já descritos na teoria transdisciplinar. Pretendeu-se relacionar os conteúdos priorizados no ensino com as características das metodologias de ligação dos saberes, com as recomendações dos documentos governamentais e com os objetivos do Projeto Político-Pedagógico e dos Planos Anuais do Curso para a Filosofia.

Ademais, segundo Marconi e Lakatos (2010, p. 176), "por mais que o observador não se envolva tanto nas situações observadas" e não vá para o campo com um programa rigidamente pré-estabelecido para a coleta de dados, "esse procedimento tem caráter sistemático", ou seja, científico. Também considerando que as práticas escolares do ensino de filosofia não são uniformes, nem em termos didáticos nem na seleção dos conteúdos abordados, como constatado por Gallo e Kohan (2004) tornou-se, de fato, inviável o pré-estabelecimento de um roteiro rígido para guiar as observações. As informações foram, inicialmente, registradas no diário de campo a cada aula observada. Posteriormente, os registros foram transcritos para uma versão digital do diário.

Para mais, a análise e interpretação dos dados bibliográficos, documentais e da incursão a campo efetivou-se por meio da técnica da análise de conteúdo. A princípio buscou-se explorar os distintos registros escritos com os seguintes propósitos: confirmar as categorias analíticas, construir um inventário, a partir da decomposição dos conteúdos dos registros, e, assim contrastá-lo com as informações oriundas das categorias analíticas; e, depois, reagrupar os elementos por categorias para em seguida classificá-los (BARDIN 1988; MINAYO, 1998). Nesse processo de ordenação da realidade investigada, chegou-se por inferências interpretativas à definição das seguintes categorias empíricas:

1) Realidade: reunião e elaboração dos dados relacionados à problemática ontológica, ou seja, sobre a organização do mundo e as percepções que se tem dele;

2) Ser Humano: reunião e elaboração dos dados referentes à problemática antropológico-filosófica, ou seja, sobre as conceituações de ser humano;

3) Conhecimento: reunião e elaboração dos dados pertencentes à problemática epistemológica, ou seja, sobre a construção ou organização do conhecimento.

Com essas categorias empíricas pretendeu-se "apreender as determinações e as especificações" que se expressaram na realidade empírica (BARDIN, 1988, p. 107). Essas categorias foram triânguladas com as categorias analíticas e demais referências. Além do mais através da interpretação dos dados construiu-se os quadros de resultados e os textos descritivos, destacando e relacionando as informações adquiridas nos processos de análise. Por fim, enfatiza-se que, a separação desses temas em três categorias não quer indicar uma dissociação entre essas temáticas cujas problematizações, evidentemente, se entrelaçam. Contudo, no presente artigo, devido à grande quantidade de dados coletados e reunidos nas categorias, serão divulgados a problematização e os resultados (considerações finais) referentes aos

SILVA, Gilson Malta da. O ensino de filosofia nas perspectivas inter e transdisciplinar: a problemática do conhecimento. Griot : Revista de Filosofia, Amargosa, Bahia, v.16, n.2, p.398-422, dezembro/2017. 
dados pertencentes à terceira categoria. No segundo e terceiro artigos, explicitaremos a análise dos dados e resultados referentes às categorias Realidade e Ser Humano.

\section{Apresentação e problematização dos dados}

Da fragmentação disciplinar ao surgimento das distintas metodologias de ligação dos saberes: uma breve contextualização

A origem do termo disciplina remete ao século XIV, quando as chamadas artes (ciências "técnicas") passaram a ser nomeadas disciplinas, "para destacar que a aprendizagem exige a submissão a uma "disciplina" (RESWEBER, 2000 apud SOMMERMAN, 2006, p. 25). O termo disciplina liga-se ainda às noções de regra, ordem e método e ao termo em latim discere, que significa aprender, mais especificamente aprendizado de um conjunto de conhecimentos referente a um recorte do saber. Weil, Ambrósio e Crema (1993, p. 33), a partir dos estudos de G. Michaud concebem disciplina como "conjunto específico de conhecimentos que possui características próprias no plano de ensino, da formação, dos mecanismos, dos métodos e das matérias". Pineau (1980 apud SOMMERMAN, 2006, p. 25), em seus estudos, interliga a raiz discere ao termo grego mathema. Esse termo refere-se a tudo que pode ser objeto de conhecimento. Desse modo, o mencionado autor, conceitua disciplina como o "aprendizado ou o ensino de uma ciência seguindo as regras e métodos da ciência a que corresponde".

Para Morin $(2010$ a) as disciplinas são produto do conhecimento científico. Quanto mais esse modelo de conhecimento desenvolveu-se, desde meados do século XIX até a segunda metade do XX, mais a fragmentação disciplinar aumentou. Contudo, essa história das disciplinas chegou a um esgotamento que se refere às possibilidades de inteligibilidade sobre vários problemas.

Ademais, a emergência do movimento Iluminista do século XVIII, seguido do positivismo do século XIX e o crescimento do volume e da complexidade dos saberes científicos reforçaram a separação disciplinar pela delimitação dos objetos do conhecimento relativo a cada ciência. Todavia, até o final do século XIX, a divisão do saber em áreas caracterizava-se mais como um processo metodológico para desenvolver as análises e teorizar as sínteses; ou, então, caracterizava-se como uma estratégia didática para transmitir os novos conhecimentos (SOMMERMAN, 2006). Por conseguinte, à medida que os diversos problemas científicos foram emergindo, delimitavam-se novas disciplinas para contemplá-los, estabeleciam-se novas fronteiras epistemológicas, criavam-se novos conceitos e técnicas para o entendimento e a resolução de cada problema. Sendo assim, esse processo culminou com a geração de especialidades disciplinares cada vez mais delimitadas e incomunicáveis tanto no âmbito da pesquisa científica como no âmbito da educação formal; nível superior e, consequentemente, nível básico.

Morin (2005a) esclarece que esse paradigma de fragmentação, redução e simplificação - denominações criadas por ele - originou-se do método cartesiano e orientou toda a produção científica moderna. Essa prática metodológica que consiste em dividir um problema complexo em parcelas simples, quantas vezes for necessário, para resolvê-lo, fundamentou também diversas formas de organizações sociais, culturais e educacionais. Desse modo, as instituições de ensino superior foram 
organizadas numa estrutura departamental com fronteiras epistemológicas bem delimitadas e rígidas, e os seus cursos formatados pelas tradicionais grades curriculares que funcionam, salvo em raros casos, como esquemas que impedem o fluxo das informações e a construção de relações entre as disciplinas e as áreas do conhecimento. Também o referido paradigma de fragmentação concretizou-se nas instituições de educação básica com a tradicional organização das matrizes curriculares que delimitam conteúdos específicos de cada saber e a divisão do tempo escolar respectivo a cada um. Isso implicou num aumento da separação entre os saberes escolares. Dessa forma, o professor crê que "a soma das partes listadas nas grades curriculares (estruturadas por meio de uma sequência de múltiplas disciplinas compartimentadas) significa o todo do conhecimento" (SANTOS, 2008, p. 19-20).

Esta perspectiva de organização curricular, que privilegia o ensino de saberes justapostos, tem dificultado o estabelecimento das relações entre os conhecimentos e o consequente reconhecimento e problematização da complexidade do real. Segundo Edgar Morin, a grande maioria dos estudantes permanece incapaz de selecionar e organizar os conteúdos assimilados em sala de aula. Os referidos estudantes não dispõem de um princípio que lhes permitam ligar os saberes e tratar os problemas complexos construindo um sentido que seja fruto de uma visão mais global da realidade. A conseqüência da vivência do referido paradigma para esses estudantes consiste em terminarem os cursos de graduação ou as etapas da educação básica com uma "cabeça bem cheia" (MORIN, 2010, p. 21) de conhecimentos justapostos, e não uma "cabeça bem feita", ou seja, capaz de organizar e relacionar os diversos saberes.

Contudo, em contraposição a esse paradigma da fragmentação, a partir de meados dos anos 50, começam a ser organizados vários esforços pela comunidade acadêmica para interligar os conhecimentos e investigar problemas cada vez mais complexos que surgiam. Pouco tempo depois, começaram a ser definidas várias nomenclaturas, com distintos prefixos, para especificar os diferentes tipos de metodologias de ligação dos saberes científicos que estavam sendo construídos. É importante ressaltar que essas distinções possuem, às vezes, caráter mais didático que metodológico. Segundo as explicitações de Nicolescu (1999, p. 54-55), a separação entre essas metodologias nem sempre é tão clara e o pesquisador assim esclarece: "A disciplinaridade, a pluridisciplinaridade, a interdisciplinaridade e a transdisciplinaridade são as quatro flexas de um único e mesmo arco: o do conhecimento". Não se tem no presente trabalho a pretensão de estabelecer fronteiras inabaláveis entre essas distintas e, ao mesmo tempo, complementares abordagens ${ }^{4}$. Todavia, com o quadro a seguir pretende-se comparar as características de cada uma das citadas metodologias.

QUADRO 1- Síntese das características das metodologias de ligação dos saberes

\begin{tabular}{|ll|}
\hline & METODOLOGIAS DE LIGAÇÃ̃ DOS SABERES - ÂMBITO DA PESQUISA CIENTÍFICA \\
\hline & \multicolumn{1}{c|}{ PLURIDISCIPLINARIDADE } \\
\hline a) & $\begin{array}{l}\text { Formas de cooperação entre as disciplinas: Justaposição de disciplinas mais ou menos vizinhas no } \\
\text { domínio do conhecimento; }\end{array}$ \\
b) Qualidade das interações: mínimas interações entre as disciplinas envolvidas; \\
c) Concepção ontológica da realidade: um único nível composto por múltiplos objetos; \\
d) Exemplos de disciplinas e/ou campos em interações: análises conjugadas pelas óticas da História,
\end{tabular}

\footnotetext{
${ }^{4}$ Conferir também Sommerman (2008, p. 63-66).
} 


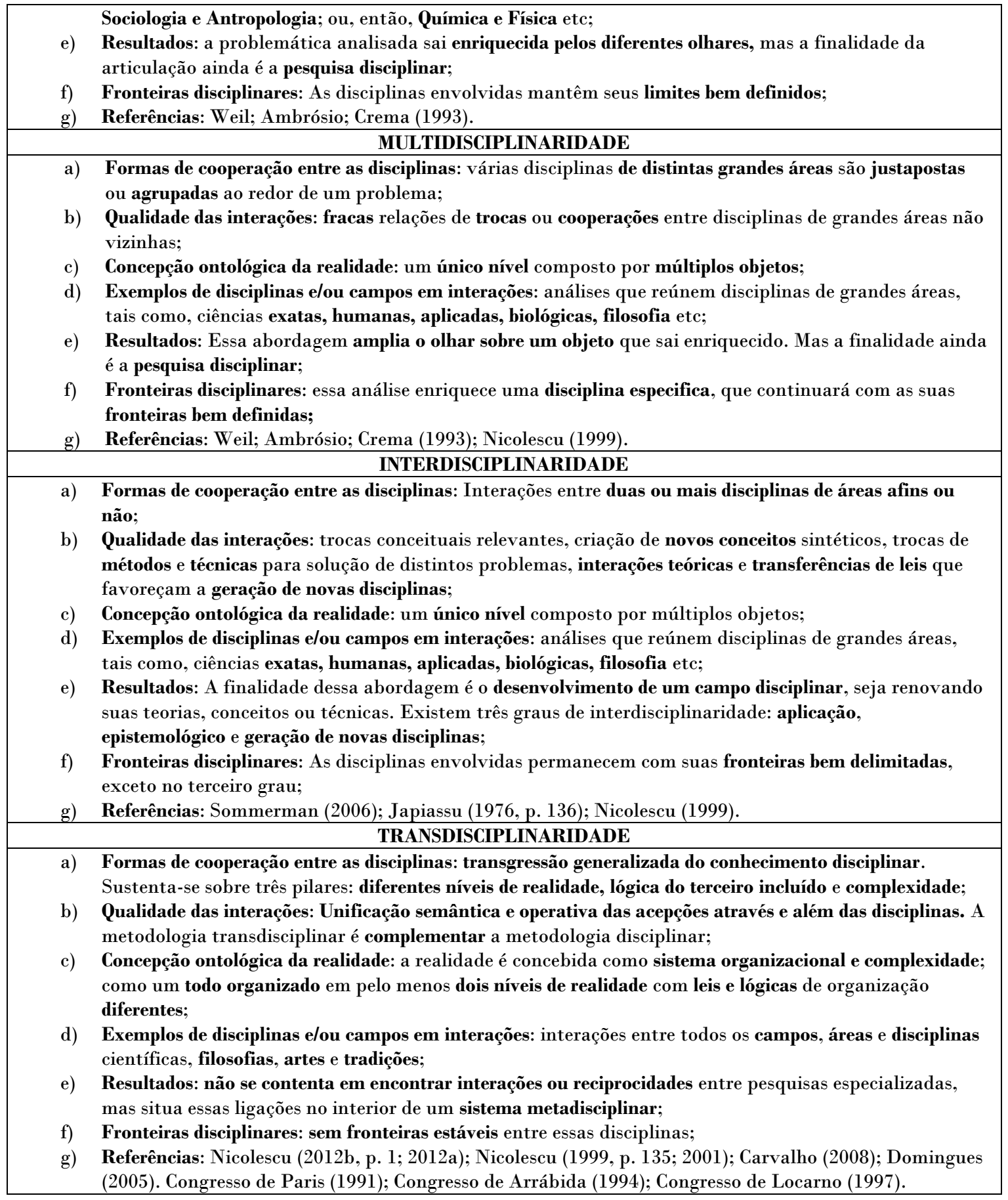

Fonte: Pesquisa bibliográfica e documental (2013)

\section{Uma análise do Projeto Político-Pedagógico do Colégio e dos Planos Anuais do Curso de Filosofia} Características do Projeto Político-Pedagógico

A análise do Projeto Político-Pedagógico do Colégio Nossa Senhora de Lourdes possibilitou verificar que a instituição tem como meta para ser alcançada em seu ensino, "a abordagem das temáticas escolares numa perspectiva transdisciplinar da realidade" (Diário de campo.). No entanto, o referido documento 
não especificava no que consistia essa perspectiva transdisciplinar de realidade. Sendo assim, para elucidá-la, necessitou-se recorrer, principalmente, às contribuições teóricas de Basarab Nicolescu e Edgar Morin.

Em termos ontológicos, a concepção transdisciplinar de realidade consiste numa organização complexa ${ }^{5}$ de uma totalidade aberta, dinâmica, multidimensional e multireferencial. Nessa totalidade aberta e dinâmica co-existem, pelo menos, dois níveis de realidade que são constituídos por leis e lógicas distintas, e, em cada nível de realidade, estão presentes distintos níveis de organização; há também diferentes níveis de percepção ${ }^{6}$. Já que a coordenação do Colégio tem por meta desenvolver uma educação transdisciplinar, ela precisa não só inserir essas questões como conteúdo curricular, desenvolvendo-as com os estudantes, mas ainda organizar o referido currículo a partir dessa nova compreensão de realidade. Entretanto, o Colégio ainda mantinha uma organização curricular tradicional. Essa nova organização curricular deve, pelo menos, atender as orientações apresentadas em (BRASIL, 2013); especialmente, naquilo que se refere ao termo "matriz curricular".

Por essa expressão, o mencionado documento, denomina uma organização curricular que assegura dinamismo e multidimensionalidade a vida curricular de tal modo que os diferentes campos de conhecimento se reúnam com o conjunto de atividades educativas. Eis aí o sentido da expressão "concepção transdisciplinar e matricial de organização curricular" que é ressaltado no texto do documento. Sendo assim, a matriz curricular constitui-se em "alternativa operacional que subsidia a gestão de determinado currículo escolar, subsídio para a gestão da escola (organização do tempo e espaço escolar; distribuição e controle da carga horária docente) e [...] gestão centrada na abordagem interdisciplinar" (BRASIL, 2013, p. 30). É importante ressaltar que, não há nesse documento governamental e nos demais citados nessa pesquisa, de modo explícito, a definição de uma concepção de transdisciplinaridade escolar derivada da concepção epistemológica de transdisciplinaridade tal qual explicitada pelos referenciais teóricos dessa pesquisa.

As observações de campo evidenciaram que o Colégio, a despeito de suas orientações normativas, não possuía um "planejamento e desenvolvimento do currículo de forma orgânica, superando a organização por disciplinas estanques e revigorando a integração e articulação dos conhecimentos, num processo permanente de interdisciplinaridade e transdisciplinaridade"; como preconiza (BRASIL, 1999 a, p. 17; itálico meu) - Parte I (Bases Legais). Esse novo planejamento consiste numa

\footnotetext{
${ }^{5}$ Por complexidade, segundo Morin (2008b) e de acordo com as explicitações elaboradas por Petráglia (2010), compreende-se um termo derivado do latim complexus e que significa aquilo que abrange muitos elementos, um conjunto de coisas interdependentes. É a congregação de elementos que são membros e partícipes do todo que não se reduz à mera soma dos elementos que o constituem.

${ }^{6}$ Para aprofundar as definições desses termos pode-se recorrer a: Nicolescu $(1999$, p. 31) e Nicolescu e Badescu (2001, p. 122) níveis de realidade e níveis de organização; Morin (2008b, p. 122-134) organização complexa; Nicolescu (1999, p. 73) e Nicolescu e Badescu (2001, p. 127 -136) totalidade aberta e dinâmica; Nicolescu e Badescu (2001, p. 120-127) leis e lógicas distintas; Nicolescu (1999, p. 31) multidimensionalidade e multireferencialidade; Nicolescu e Badescu (2001, p. 122) níveis de organização; Silva (1999, p. 12) níveis de percepção. Em artigo posterior, apresentaremos a análise dos dados relativos ao conjunto das aulas nas quais foi abordada a problemática ontológica e explicitaremos detalhadamente esses termos.
}

SILVA, Gilson Malta da. O ensino de filosofia nas perspectivas inter e transdisciplinar: a problemática do conhecimento. Griot : Revista de Filosofia, Amargosa, Bahia, v.16, n.2, p.398-422, dezembro/2017. 
"reorganização curricular em áreas de conhecimento, com o objetivo de facilitar o desenvolvimento dos conteúdos, numa perspectiva de interdisciplinaridade e contextualização" (Idem; itálico meu).

No texto do Projeto Político-Pedagógico encontrou-se ainda a seguinte informação: "o eixo organizador da matriz curricular é a conjunção da interdisciplinaridade e de um ensino contextualizado" (Diário de campo.). Esta informação constava na seção da organização curricular que se referia não só ao ensino médio, mas a toda a educação básica. No entanto, esses termos apareciam no documento escolar sem maiores esclarecimentos sobre o que consistiriam interdisciplinaridade e contextualização no âmbito escolar e ainda como esses conceitos se concretizariam nas vivências escolares.

Sendo assim, recorremos a Brasil (1999 a), com o objetivo de melhor compreender a interdisciplinaridade e a contextualização no âmbito da educação escolar. $O$ texto do documento governamental esclarece que o conceito de interdisciplinaridade parte de dois pressupostos que, de modo geral, são fáceis de serem reconhecidos por todos, a saber: "que todo conhecimento mantém um diálogo permanente com outros conhecimentos, que pode ser de questionamento, de confirmação, de complementação, de negação, de ampliação, de iluminação de aspectos não distinguidos" e "algumas disciplinas se identificam e aproximam, outras se diferenciam e distanciam, em vários aspectos: pelos métodos e procedimentos que envolvem, pelo objeto que pretendem conhecer, ou ainda pelo tipo de habilidades que mobilizam naquele que a investiga, conhece, ensina ou aprende" (Ibid., p. 75; itálico meu). Nesse sentido, "a interdisciplinaridade tem uma função instrumental". (Ibid., p. 21). Trata-se de estabelecer, por meio de práticas escolares, "interconexões e passagens entre os conhecimentos através de relações de complementaridade, convergência ou divergência" (Idem). Com a interdisciplinaridade escolar não se pretende criar novas disciplinas ou saberes escolares, mas articular conhecimentos de várias disciplinas a fim de solucionar um problema concreto ou então problematizar um determinado fenômeno a partir de diferentes pontos de vista.

Outrossim, contextualizar significa constituir conhecimentos num processo permanente de trânsito do plano da experiência imediata para o plano das abstrações e, deste, para a reorganização sistemática da experiência imediata e, assim, envolver numa relação ativa o sujeito conhecedor e objeto conhecido. Nesse sentido, Minas Gerais (2006, p.14) destaca, sobre os temas que serão objetos da reflexão filosófica, que o "[...] objetivo é que, partindo da experiência, se chegue ao tratamento filosófico do tema, ou seja, que ele possa ser abordado através de conceitos" (itálico meu). A contextualização busca desenvolver aprendizagens significativas que são produzidas evocando-se "áreas, âmbitos ou dimensões presentes na vida pessoal, social e cultural dos discentes (BRASIL, 1999a, p. 78). Ademais, Brasil (1999a) denomina a contextualização e a interdisciplinaridade de princípios pedagógicos estruturadores das matrizes curriculares das unidades educacionais. Com a persistência da problemática da compartimentação do conhecimento escolar, Brasil (2012) enfatiza novamente a validade desses princípios.

Para a concretização da explicitada proposta educacional é necessário não somente elaborar uma nova organização curricular, mas recriar os tempos e espaços escolares. Essa transformação pressupõe educadores dispostos e preparados para 
reinventar o ambiente escolar (BRASIL, 2013). Todavia, o Colégio não havia sido reorganizado para subsidiar o trabalho dos profissionais da educação com as metodologias pluri, inter ou transdisciplinar que requerem "a atenção criteriosa da instituição escolar" porque "perpassam todos os aspectos da organização escolar, desde o planejamento do trabalho pedagógico, a gestão administrativo-acadêmica, até a organização do tempo e do espaço físico e a seleção, disposição e utilização dos equipamentos e mobiliário da instituição" (Ibid., p. 27).

\section{Características dos Planos Anuais do Curso de Filosofia}

Analisando os Planos Anuais do Curso de filosofia para os três anos do ensino médio, o professor Fábio ${ }^{7}$ destaca, como subtítulo, que se trata de uma "proposta interdisciplinar de ensino" (Diário de campo). A ementa dessa proposta informava que as temáticas ensinadas aos estudantes seriam inseridas em um debate interdisciplinar. Do mesmo modo, consta no subtítulo denominado de metodologia pedagógica que "o processo ensino-aprendizagem mediado pelo professor propõe despertar os estudantes para realizarem operações tais como comparar, associar, sintetizar, justificar, interpretar e relacionar ideias baseando-se em práticas interdisciplinares" (Idem). Por fim, no subitem ações didáticas, novamente aparece uma referência à construção de práticas que privilegiem o processo interdisciplinar.

Os mencionados documentos ${ }^{8}$ não apresentavam maiores explicitações a respeito das expressões "proposta interdisciplinar de ensino", "debate interdisciplinar", "práticas interdisciplinares" e "processo interdisciplinar". Essas expressões simplesmente constavam no texto do citado documento. Observou-se que a mediação realizada pelo professor tinha por objetivo problematizar temáticas contidas no livro didático ou provenientes de outras fontes trazidas pelo professor e estudantes, como a internet, por exemplo. Considerando o fato de não haver um planejamento pedagógico institucional baseado no conceito de interdisciplinaridade escolar, assim como apresenta Brasil (1999a, p. 21), ou seja, articulação de conteúdos de várias disciplinas, o que inclui a filosofia, a fim de "resolver um problema concreto ou compreender um determinado fenômeno", o que estava sendo desenvolvido naquele espaço educativo formal e sendo interpretado como "interdisciplinaridade escolar" consistia em problematizar um tema filosófico, fazendo menções a aspectos ou conteúdos de outras disciplinas. Essas menções emergiam da exposição do professor, com base nos materiais didáticos ou nos debates entre ele e os estudantes. No entanto, o desenvolvimento da interdisciplinaridade escolar, como já visto, depende da reorganização da unidade educativa em muitos aspectos.

Embora os Planos Anuais do Curso de filosofia apresentassem uma proposta interdisciplinar de ensino que tinha por objetivo realizar debates e práticas interdisciplinares, ou seja, ações didáticas por meio de um processo interdisciplinar, não foi observada, em nenhuma das aulas de filosofia, a participação de professores de outras disciplinas nas mediações didáticas e problematizações das temáticas

\footnotetext{
${ }^{7}$ Os nomes citados nessa pesquisa são fictícios.

${ }^{8}$ Para maiores explicitações sobre os tipos ou tendências predominantes de ensino de filosofia no Brasil, conferir: Gallo e Kohan (2000), Gallo et al., (2004). Contudo, o objetivo principal dessa pesquisa não foi analisar o ensino de filosofia a partir das características dessas tendências.
} 
estudadas. Brasil (1999b, p. 18) esclarece que, para desenvolver a interdisciplinaridade escolar, nem sempre é necessário um trabalho coletivo entre os docentes de distintas disciplinas. Por esse ângulo "no interior de uma única disciplina [...] um certo conteúdo pode ser desenvolvido com uma perspectiva intra-área [...] ou inter-áreas [...] sem precisar de um acordo interdisciplinar envolvendo diferentes professores". Todavia, explorar essa possibilidade de tratar um tema próprio a uma disciplina com contexto e interdisciplinaridade sem o envolvimento de mais de um docente pode tornar-se algo problemático. Nesse sentido, o referido documento ressalta também que há temáticas como, por exemplo, "quando na biologia se fala em energia da célula, na química se fala em energia da reação e na física em energia da partícula", que para serem mais bem exploradas seja numa perspectiva intra-área ou inter-área é imprescindível a colaboração entre docentes de distintas disciplinas escolares (BRASIL, 1999b, p. 19). Igualmente nas ciências humanas há temas muito complexos que um único professor não ficaria a vontade para interpretar seu significado em outra disciplina.

Em relação à interdisciplinaridade e o ensino de filosofia, Brasil (1998); Art. $10, \S 2^{\circ}$, destaca que “As propostas pedagógicas das escolas deverão assegurar tratamento interdisciplinar e contextualizado para: [...] Conhecimentos de filosofia $[\ldots]$ ".. Para Brasil (2006, p. 18)

a compreensão da filosofia como disciplina reforça, sem paradoxo, sua vocação transdisciplinar, tendo contato natural com toda ciência que envolva descoberta ou exercite demonstrações, solicitando boa lógica ou reflexão epistemológica. Da mesma forma, pela própria valorização do texto filosófico, da palavra e do conceito, verifica-se a possibilidade de estabelecer proveitoso intercâmbio com a área de linguagens. Além de contribuir para a integração dos currículos e das outras disciplinas.

Nesse sentido, aparentemente paradoxal, reconhecer a filosofia como disciplina, com conteúdo próprio e textos específicos, é condição indispensável para que ela possa contribuir no debate interdisciplinar. Todavia, não se pode desconsiderar ou menosprezar seu potencial para pensar transdisciplinarmente uma vez que "a filosofia antecede, histórica e essencialmente, toda divisão disciplinar" (RIO DE JANEIRO, 2006, p. 23). Nessa concepção, pensar filosoficamente significa habitar um "entre - mundos", caminhar na "encruzilhada dos saberes, território de fronteiras indiscerníveis" (Idem); pois, o que distingue o saber filosófico do conhecimento científico não consiste na delimitação de um objeto, mas no "modo de tomá-lo" (Idem).

Outrossim, Minas Gerais (2006, p. 10) recomenda o seguinte: "textos científicos e literários, filmes, obras de arte e mesmo acontecimentos podem e devem estar presentes na sala de aula, não apenas como elementos motivadores, mas também como objetos de uma genuína leitura filosófica". Faz-se mister ressaltar que, o ensino organizado pelo docente estava em consonância com a citada recomendação. Pode-se destacar não só a utilização de textos literários e filmes nas aulas, mas ainda a inserção de acontecimentos cotidianos, vivenciados pelos estudantes, em algumas temáticas abordadas durante sua mediação. Isso será evidenciado mais adiante em publicações ulteriores. No entanto, as temáticas abordadas sobre o conhecimento foram trazidas pelo docente e não partiram das vivências dos estudantes. 
Em sentido semelhante ao que foi exposto anteriormente, Morin (2010 a, p. 23) defende que

\begin{abstract}
A filosofia é, acima de tudo, uma força de interrogação e de reflexão, dirigida para os grandes problemas do conhecimento e da condição humana. A filosofia, hoje retraída em uma disciplina quase fechada em si mesma, deve retomar a missão que foi a sua - desde Aristóteles a Bérgson e Husserl - sem, contudo, abandonar as investigações que lhe são próprias.
\end{abstract}

O autor não reduz o saber filosófico ao campo estritamente disciplinar e concebe a filosofia a partir de termos como "interrogação e reflexão". Contudo, a filosofia não deve abandonar eventuais questões próprias e deve refletir sobre várias questões da condição humana; o que, evidentemente, envolve a articulação de outros conhecimentos. Em certa conformidade com Edgar Morin, para Japiassu (2006, p. 159), a filosofia consiste na "busca da verdade a respeito do Todo da realidade". Sendo assim ela não pode ser considerada uma disciplina como as outras, pois "não reconhece nenhum objeto como lhe sendo exterior e escapando a sua atividade reflexiva" (Idem). Tal concepção é bem similar àquelas que foram apresentadas em Brasil (2006) e Rio de Janeiro (2006).

Ainda sobre as relações entre a filosofia e outros conhecimentos, Hilton Japiassu ainda acrescenta que os estudos filosóficos devem se abrir aos conhecimentos produzidos nas ciências humanas e sociais e que "os filósofos são muito mais úteis a sociedade participando de equipes multi-, inter- ou transdisciplinares" (Idem). Todavia, suas contribuições filosóficas no movimento de ligação dos saberes devem consistir em "manter aberto um espaço mental que resista a toda tentativa de confinamento ou reducionismo epistemológico" (JAPIASSU, 1976, p. 203). Sem despresar as devidas distinções entre disciplinas científicas e escolares ${ }^{9}$, acreditamos que as concepções de filosofia apresentadas por Morin e Japiassu sobre o saber filósofo, no âmbito da pesquisa, tornam-se pertinentes também ao saber filosófico no âmbito escolar.

\title{
O Ensino de filosofia no Colégio Nossa Senhora de Lourdes
}

Na categoria 3 - Conhecimento (perspectiva epistemológica) - foram reunidos tanto os dados emergentes durante as observações das aulas quanto àqueles coletados em Marina (2010), mas que não foram inseridos no ensino de filosofia pelo docente; contudo, referem-se à problemática da construção do conhecimento por meio de menções a outros campos disciplinares. Alguns desses temas foram abordados pelo professor no mesmo sentido dado pelo autor do livro didático. Outros

\footnotetext{
9 Segundo Brasil (1999a, p. 109) é preciso diferenciar a disciplina no sentido escolar da ciência ou corpo de conhecimentos. [...] A expressão "disciplina escolar" refere-se a uma seleção de conhecimentos que são ordenados e organizados para serem apresentados ao aluno, recorrendo como apoio a essa apresentação, a um conjunto de procedimentos didáticos e metodológicos e de avaliação. Uma disciplina escolar é, de um lado, mais limitada do que uma "matéria", ciência ou corpo de conhecimentos. [...] De outro a disciplina escolar é mais ampla, pois inclui os "programas" ou formas de ordenamentos, sequenciação, os métodos para seu ensino e a avaliação da aprendizagem. A disciplina escolar supõe ainda uma teoria de aprendizagem adequada à idade a quem vai ser ensinada [...]. Conferir ainda Chervel (1990).
}

SILVA, Gilson Malta da. O ensino de filosofia nas perspectivas inter e transdisciplinar: a problemática do conhecimento. Griot : Revista de Filosofia, Amargosa, Bahia, v.16, n.2, p.398-422, dezembro/2017. 
foram abordados em perspectivas distintas daquelas enfatizadas pelos autores. E, algumas temáticas constantes nos livros didáticos não foram abordadas pelo docente em sua mediação.

\section{QUADRO 2- Temáticas, problemas e definições encontrados em Marina (2010)}

\section{TEMÁTICAS, PROBLEMAS E DEFINIÇÕES}

a) Introdução: uma vida inteligente e nobre

[...] A filosofia é um pensamento rigoroso que tem como objetivos refletir e investigar o mundo em que vivemos, questionando modelos, problematizando valores e práticas. Para "fazer filosofia", convém aprender a pensar bem, saber o que outros (filósofos, poetas, psicólogos, cientistas, etc.) pensaram sobre a vida e sobre o mundo, saber interpretar teorias e conceitos e verificar a validade dos argumentos. [...] (p. 9; aspas duplas do autor, sublinhado meu).

b) 0 pensamento, os problemas e os saberes

1. (os problemas e as perguntas) [...] As maiores conquistas da física moderna se devem ao audaz impulso com que o homem, em lugar de seguir a natureza, se antecipa a ela, valendo-se de uma interrogação. Para chegar a verdade, em um acordo da inteligência com as coisas, supõe-se uma certa maneira de se perguntar por ela. (MARINA, 2010, p. 12); fragmento de texto da obra (ZUBIRI, Xavier. Naturaleza, História, Dios. Madrid: Alianza Editorial, 1999).

2. [...] Os animais também têm problemas, como fugir, salvar-se, caçar, mas eles os resolvem aproveitando os mecanismos instintivos. Os seres humanos, por sua vez, fazem perguntas que revelam o problema, qualificando-o, criando possibilidades para sua resolução, por meio do pensamento. (Idem, negrito do autor, sublinhado meu).

3. Alexandre Fleming (1881-1956), importante biólogo britânico, estudava alguns tipos de bactérias. Para isso, ele cultivava as bactérias em lâminas de vidro. Um dia, revisando as lâminas, viu que em uma delas as bactérias não tinham crescido ao redor de uma zona contaminada por fungos. Qualquer outra pessoa jogaria a lâmina fora, achando que estava estragada, mas Fleming se fez uma pergunta muito importante: Por que esse fungo impediu que as bactérias crescessem? Dessa pergunta surgiu a penicilina, um antibiótico obtido do fungo, que foi o primeiro medicamento realmente efetivo contra as infecções bacterianas (Idem).

4. (O pensamento nos diferentes saberes) [...] Todas as disciplinas que estudamos pretendem ensinar a pensar uma determinada área do conhecimento. A matemática, por exemplo, ensina a pensar sobre os números, relações e operações. A física ensina a pensar sobre o movimento e outros fenômenos da natureza. A ética ensina a pensar e a problematizar as diversas formas de conduta e comportamento. [...] No caso da filosofia, é fundamental entender que: Filosofar é uma atividade, é o exercício do pensamento e da reflexão. A filosofia reflete sobre tudo o que a inteligência humana faz, sobre tudo o que se conhece, sobre sentimentos e ações. Cada disciplina trata de um conhecimento específico, enquanto a filosofia é mais abrangente. Ela pergunta: O que é o conhecimento? Quais são os fundamentos dessa áreas do saber? [...] Por isso, do ponto de vista da filosofia, podemos perguntar sobre todas as demais disciplinas (MARINA, 2010, p. 13; negrito do autor, sublinhado meu).

5. (Diferenças no pensamento) [...] Todas as áreas do conhecimento apresentam modos específicos de pensar [...] A diferença entre elas é que lidam com diferentes informações, fazem diferentes perguntas, têm critérios diversos para resolver problemas. [...] Enquanto as informações, as metas e os métodos mudam de uma área do conhecimento para outra, as operações realizadas ao pensar são comuns, ainda que às vezes não pareçam. Exatamente por serem comuns é que podemos usar a mesma inteligência para pensar em coisas tão diferentes. (Idem, negrito do autor)

c) Os aspectos comuns ao pensamento

Para compreender os aspectos comuns a toda forma de pensar, vamos comparar dois exemplos de pensamento: o poético e o matemático. Esta é outra característica da filosofia: relacionar conhecimentos ou atividades diversas (MARINA, 2010, p. 14; negrito do autor, sublinhado meu).

(O pensamento poético) - Vamos ler os seguintes versos do poeta chileno Pablo Neruda.

Na noite, na tua mão; Brilhou como um vaga-lume;

Meu relógio

Quais foram as operações que o poeta realizou para escrever esses versos ou quais são as operações que nós deveríamos realizar para escrever um texto semelhante? Neruda buscou algo que fosse parecido a esfera de um relógio brilhando na escuridão e encontrou um "vaga- lume". No lugar de dizer "Na noite, na tua mão brilhou a esfera luminosa do meu relógio", escreveu "brilhou como um vaga-lume meu relógio". As operações feitas são 
buscar um aspecto análogo ao que se quer dizer e substituir um pelo outro. Essa é uma operação característica do pensamento poético, uma metáfora que conecta uma realidade com outra análoga. (Idem, p. 14)

(O pensamento matemático) - Vejamos agora um exemplo matemático. "Um número elevado a potência zero é igual a um", na expressão matemática, $\mathbf{a}^{0}=1$. Essa frase parece incompreensível. O que o matemático faz para poder compreendê-la.? Procura elementos análogos, que na matemática devem ser semelhantes e produzir a mesma resposta, e não aproximações, como na poesia de Neruda. Que outras coisas são iguais a zero? O resultado de uma subtração $(\mathrm{x}-\mathrm{x}=0$ ). Agora, tal como fez Neruda no poema, vamos substituir o zero pela subtração de um número por si mesmo: $\mathbf{a}^{(\mathrm{x}-\mathrm{x})}=1$.[...] Continuemos buscando elementos análogos. [...] Como se dividem as potências de mesma base? Subtraindo os expoentes. [...] A expressão a $\mathbf{a}^{(\mathrm{x}-\mathrm{x})}$ é igual a uma divisão: $\mathrm{a}^{\mathrm{x}}$ dividido por $a^{\mathbf{x}}$ [...] Qual é o resultado de um número dividido pelo mesmo número? Sempre será 1. [...] Depois de buscar casos análogos (neste caso, com resultados iguais) e de substituí-los na expressão original, sabemos por que um número elevado a zero é igual a um (Idem, p. 14; negrito do autor, sublinhado meu).

d) 0 que é o pensamento filosófico

(Elementos do pensamento filosófico) [...] Informação. A filosofia se interessa pela própria inteligência e pela realidade de uma forma geral. Na Antiguidade grega, Aristóteles de Estágira dizia que a filosofia "é o conjunto de todo o saber humano" de modo que não há um campo determinado como nas outras disciplinas (MARINA, 2010, p. 15; sublinhado meu). Metas. As duas grandes metas da filosofia são o conhecimento e a felicidade [...] A física e as ciências naturais tratam do conhecimento da natureza, e a história, dos acontecimentos humanos ocorridos no passado. A filosofia, por sua vez, não se satisfaz apenas com os resultados apresentados pelas ciências e sempre procura ir além, até mesmo discutindo as categorias de análise das ciências e seus propósitos sociais e políticos. Todas as ciências pretendem conhecer a verdade, mas a filosofia pergunta: $\mathrm{O}$ que é a verdade? [...] Operações mentais. A filosofia utiliza as mesmas operações mentais que as outras ciências. Métodos. A filosofia tem como método a argumentação e a justificação racional (MARINA, 2010, p. 15).

[...] Para os gregos, "filosofia" era "o amor à sabedoria". Assim, todas as pesquisas científicas eram "filosofia" e a palavra "filosofia" tinha o mesmo significado que "ciência" [...] Do núcleo comum da ciência única e universal chamada "filosofia" começaram a se separar as várias ciências [...] as diferentes especialidades que originaram historicamente as ciências naturais, as exatas e a humanas (Idem); fragmento de texto da obra (AJDUKIEWICZ, Kazimierz. Introducción a la filosofia-epistemologia y metafísica. Madrid: Cátedra, 1986).

e) A utilidade da filosofia

São os objetivos principais da filosofia:

Ensinar a pensar bem. Cada área do conhecimento ensina a pensar de uma determinada maneira. A filosofia encarrega-se do pensamento em geral, das normas da lógica, de avaliar a verdade, de perceber a diferença entre o pensamento teórico e o prático. Ajudar a entender a realidade. Enquanto os outros saberes se encarregam de uma parcela da realidade - a história, a arte, a astronomia, a biologia, etc, - , a filosofia encarrega-se da totalidade dos seres, de suas propriedades mais comuns e de suas relações com o meio e com outros indivíduos. [...] Busca respostas às perguntas que estão além do campo de cada uma das ciências (MARINA, 2010, p. 17; negritos do autor; sublinhado meu).

Fonte: pesquisa documental (2013)

\section{QUADRO 3- Temáticas, problemas e definições encontrados em Marina (2010)} TEMÁTICAS, PROBLEMAS E DEFINIÇÕES

a) Filosofia: autoanálise e sistema

(A filosofia como sistema) [...] A filosofia ensina a pensar, mas não oferece uma solução definitiva. Ela apresenta formas distintas de refletir sobre as mesmas questões, e convém conhecê-las, porque as idéias filosóficas influem em nossa maneira de pensar e de interpretar a ciência e a religião, de ordenar os assuntos humanos e de afirmar ou negar os valores éticos em geral (Idem, p. 30; sublinhado meu).

\section{b) Filosofia e verdade}

(a filosofia como um saber radical) [...] A filosofia é um saber radical porque se propõe problemas últimos e primeiros, e porque se esforça em pensá-los de modo radical. Esse radicalismo do pensamento filosófico o distingue dos outros modos de conhecimento; sobretudo, o das ciências, porque estas, longe de se proporem problemas radicais, não [os] admitem mais em princípio [como] suscetíveis de solução, portanto, problemas mansos, como animais domésticos [...]. Mas os problemas da filosofia são os problemas absolutos e são absolutamente problemas, sem limitação nenhuma de seu brio pavoroso; são os problemas ferozes que amedrontam e angustiam a existência humana, dos que o homem é portador e sofredor permanente (MARINA, 2010, p. 34; sublinhado meu); fragmento de texto da obra (ORTEGA y GASSET, José. Sobre la razón histórica. Madrid: Alianza Editorial, 1988).

c) Perguntas da filosofia

(o que posso conhecer): [...] A condição humana apresenta numerosas facetas, por isso a filosofia não se detém aos limites da ciência com seu método. Ela quer conhecer mais, quer encontrar um sentido completo para a

SILVA, Gilson Malta da. O ensino de filosofia nas perspectivas inter e transdisciplinar: a problemática do conhecimento. Griot : Revista de Filosofia, Amargosa, Bahia, v.16, n.2, p.398-422, dezembro/2017. 
existência. Assim, investiga os limites do conhecimento e da verdade, mas tampouco se conforma com eles, lançando-se a novas buscas e ampliando as respostas (Idem, p. 36; sublinhado meu).

(o que posso esperar): A filosofia ocupou-se, desde sua origem, do estudo da condição humana; entendeu o homem como um ser biológico, sujeito às mesmas leis naturais que os outros seres, mas com características próprias e exclusivas, como a racionalidade, a liberdade, a sociabilidade, a arte, a linguagem. Considerando todas essas dimensões naturais e culturais, assim como as contribuições de outras ciências (paleontologia, história, arqueologia, biologia, genética, etc.), a história da filosofia nos oferece diversas teorias ou concepções sobre o ser humano e sua humanidade (Idem, p. 37; sublinhado meu).

d) Aprender a ler filosofia

(A compreensão) : [...] A palavra "compreender" significa captar tudo de uma vez, prender tudo junto. Dar um significado único as coisas que antes estavam separadas. Reorganizar todas as peças de outra maneira. [...]

(Completar as lacunas): Como funciona o processo de compreensão de um texto? Leiamos o seguinte texto de Liev Tolstói (1828 - 1910), grande escritor russo do século XIX:

Um corvo ouviu que davam muito bem de comer aos pombos, então se pintou de branco e voou para o pombal. Os pombos pensaram que eram um pombo e o receberam bem. No entanto, não pôde conter-se e deu um grito como um corvo. Então, os pombos compreenderam que era um corvo e o mandaram para fora do pombal. Regressou com os seus, mas então estes não o reconheceram e tampouco o quiseram acolher (MARINA, 2010, p. 38); fragmento de texto da obra (TOLSTÓI, Liev. O corvo e o pombo. In: Contos da nova cartilha. Cotia: Ateliê, 2005).

Analisemos a grande quantidade de coisas que tivemos de supor para entender esse texto. Vejamos a primeira frase: Um corvo ouviu que davam muito bem de comer aos pombos (e quis desfrutar como eles), então se pintou de branco (os corvos são escuros e os pombos são brancos, e ele queria parecer um pombo para que não o reconhecessem) e voou para o pombal (para comer tão bem como os pombos). [...] Em qualquer texto, há muitas coisas que não são ditas, e que o leitor deve supor ou inferir. Ao ler, completamos o texto com o que sabemos. Compreendemos a história do corvo e do pombo porque, sem dar-nos conta, aplicamos nos corvos e nos pombos o que sabemos sobre os humanos. Ou seja, supomos corretamente que o autor estava "humanizando" as aves que protagonizam o texto. Portanto, um dos métodos para "buscar a compreensão" é completar as lacunas que o texto têm, as suposições implícitas (Idem; itálicos do autor, sublinhado meu).

Fonte: pesquisa documental (2013)

\section{A filosofia e o conhecimento}

O professor Fábio iniciou o ensino da temática do conhecimento buscando relacionar a filosofia, o filósofo e o conceito filosófico. Em primeiro lugar, o docente caracterizou o saber filosófico como "a busca da verdade", no sentido de "aletheia ou desvelamento" (Diário de campo). Afirmou ainda que a filosofia é " uma área fundamental do conhecimento, pois a atividade filosófica caracteriza-se pela busca de conceitos ou idéias, compreendidos como imagens mentais, que ajudam o filósofo a refletir sobre os vários objetos da realidade" (Idem). Diversamente, a concepção de filosofia apresentada por Marina no (Quadro 2, a) centrava-se mais na idéia de investigação rigorosa do mundo - problematização de modelos, valores, práticas, argumentos, conceitos e teorias - e comunicação entre diversos saberes pela aprendizagem mútua entre filósofos, poetas, psicólogos, cientistas e outros.

Além disso, Marina destaca que, para os gregos, a filosofia, em seu início, mantinha uma relação estreita com os outros conhecimentos. Da "ciência única" começaram a se separar as várias especialidades que historicamente originaram as conhecidas denominações ciências naturais, exatas e humanas. Pautando-se no método da argumentação e justificação racional, o filósofo não se limita aos resultados apresentados pelas demais ciências problematizando para além deles. As informações que o filósofo dispõe para elaborar determinado conhecimento não estão 
limitadas à um recorte da realidade como no caso dos pesquisadores das disciplinas científicas. O filósofo problematiza, por exemplo, os pressupostos epistemológicos, sociais e políticos das demais ciências e suas categorias de análise (Quadro 2, d, e).

A este conteúdo, Fábio acrescentou que "filosofar consistiria em pensar as questões da vida por si mesmo" (Diário de campo). O estudante Sérgio questionou o seguinte: "Essa atividade filosófica estava sendo compreendida como pensar sem pressupostos ou ideologias norteadoras? Se assim fosse, essa atividade seria muito complicada para ser vivida, pois os seres humanos parecem estar sempre agindo pela inspiração de uma ideologia ou prévia visão de mundo" (Idem). Após essa apreciação do discente, o professor Fábio explicitou que "filosofar consistiria em viver de modo inteligente - uma vida verdadeiramente humana- avaliando nossa maneira de ser e de agir, ainda que reconhecendo os determinismos genéticos, sociais econômicos, culturais, políticos" (Idem). Segundo ele, esse modo inteligente, equivale a "viver diferente da maioria das pessoas que apenas seguem uma ideologia sem questionar modelos, valores e práticas consolidadas" (Idem).

Ademais, Marina elucida que o próprio saber filosófico apresenta modos distintos de pensar os mesmos problemas. $\mathrm{O}$ autor do livro didático destaca ainda que as ideias filosóficas influenciam o modo como se pensa e interpreta a ciência e a religião (Quadro 3, a). Também, com o propósito de destacar mais uma característica da filosofia, ou seja, o seu caráter radical, Marina (2010) introduz um fragmento de texto de José Ortega y Gasset. Segundo esse filósofo a radicalidade filosófica consiste em pensar problemas últimos e primeiros sem limitação alguma. Destaca ainda que essa radicalidade filosófica consiste na principal diferença entre filosofia e ciências, pois essas não admitem mais os problemas radicais como passíveis de solução (Quadro 3; b).

\section{Os conceitos filosóficos}

Tendo por base o texto do livro didático do $1^{\circ}$ e do $2^{\circ}$ ano que denomina os conceitos como "conjuntos de traços, notas ou aspectos que permitem identificar ou classificar seres e coisas" (MARINA, 2010, p. 51), o docente destacou que os conceitos filosóficos são representações e não cópias dos entes externos. Acrescentou ainda o seguinte: quanto maior a compreensão em um conceito, menor a sua extensão. Por compreensão entende-se o "conjunto de aspectos que definem um conceito" e por extensão denomina-se o "conjunto de seres identificados mediante um conceito" (MARINA, 2010, p. 51); por exemplo, "a compreensão do conceito "gato" é maior que a compreensão do conceito "mamífero" e, portanto, sua extensão é menor" (Diário de campo). Sendo assim, definir um conceito de alguma coisa é assinalar os aspectos que permitem distingui-la das demais e incluí-la num grupo ou numa categoria. Segundo o docente a melhor definição é aquela que distingue as características essenciais - referentes a todos os exemplares investigados - das características acidentais - pertencentes a apenas alguns dos exemplares. Ressaltou ainda que, tradicionalmente, na história da filosofia, distingue-se a essência, conjunto de características de um ente que não podem modificar sem que o ente deixe de ser o que é, do acidente, que consiste no conjunto de características que podem modificar sem que a essência do ente se modifique. 
Ao problematizar os conceitos filosóficos com os estudantes do $1^{\circ}$ ano, Fábio explicitou que, etimologicamente, conceito significa "conceber", "engendrar" e que o ser humano não cria apenas conceitos de coisas existentes, mas, associando aspectos de entes, ele cria "conceitos" ou ideias de coisas fantasiosas como, por exemplo, uma sereia; reunião de aspectos ou características da mulher e do peixe. Durante a exposição dessas características dos conceitos, o docente abordou também o fenômeno da circulação dos conceitos entre os campos disciplinares, da seguinte maneira:

\begin{abstract}
devido à complexidade de determinados problemas abordados por distintas áreas do conhecimento e à falta de termos adequados dentro do universo conceitual dessas áreas para caracterizar os problemas investigados, costuma acontecer um fenômeno interdisciplinar denominado de migração de conceitos. Esse fenômeno pode ser exemplificado pelo conceito estresse que foi originariamente criado na física, para expressar a situação de um objeto que foi projetado para aguentar determinada tensão e, num determinado teste, não resiste a essa tensão. Esse conceito migrou para a psicologia para designar a estafa mental que leva determinadas pessoas a sentirem dores ou desenvolverem outras manifestações corporais, como o surgimento de manchas, por exemplo. (Diário de campo) ${ }^{10}$.
\end{abstract}

Com essa explicação, o docente evidenciou um modo de comunicação entre as disciplinas ou áreas do conhecimento, no caso exposto, entre a física e a psicologia. $\mathrm{O}$ fenômeno da migração de conceitos é, até certo ponto, recorrente na pesquisa científica, conforme explicitam (DOMINGUES, 2004; MORIN, 2010). Entretanto, trata-se de um assunto pouco mencionado quando se trata do ensino de filosofia. Vale ressaltar que essa problemática não constava em Marina (2010) nem Cotrim (2010) que destacam uma definição de conceitos mais tradicional na história da filosofia.

Do nosso ponto de vista, consideramos pertinente em um ensino de filosofia que se pretenda como inter e/ou transdisciplinar, a introdução da idéia de conceito presente em Deleuze e Guattari (1992). Ao comentar esses filósofos, Gallo (2006; 2007) elucida que os conceitos não estão prontos para serem descobertos, devem ser inventados pelo filósofo que o tem em potência. Os citados filósofos organizam a noção de conceito em relação com as três potencias do pensamento que, segundo eles, é a filosofia, a ciência e a arte. Os filósofos esclarecem que não se está entendendo conceito como uma simples definição ou um nome dado a alguma coisa, mas como uma "ferramenta" mental que articula ideias diversas e ultrapassa fronteiras epistemológicas.

[...] O conceito não é paradigmático, mas sintagmático; não é projetivo, mas conectivo; não é hierárquico, mas vicinal; não é referente, mas consistente. É forçoso, daí, que a filosofia, a ciência e a arte não se organizem mais como os níveis de uma mesma projeção e, mesmo que não se diferenciem a partir de uma matriz comum, mas se coloquem ou se reconstituam imediatamente numa interdependência respectiva, uma

\footnotetext{
${ }^{10}$ Para aprofundar a questão da migração disciplinar do conceito estresse, conferir FARIAS (1984).
} 
divisão do trabalho que suscita entre elas relações de conexão (DELEUZE; GUATTARI, 1992, p. 188-119).

Ora, se criar conceitos significa conectar idéias e se as potências do pensamento podem se reconstituir numa interdependência que originam relações de conexão então a articulação de idéias entre essas potências do pensamento criando, recriando e organizando conceitos pode contribuir significativamente para a comunicação entre os diversos saberes. Ainda sobre esse assunto, vale destacar que, na exposição do professor, percebe-se a idéia de que os conceitos filosóficos são criados para dar conta de problemas, contudo, não fica explicita a possibilidade de criar conceitos articulando idéias de distintos saberes.

\section{O filósofo e o conhecimento}

Em outro momento da observação, o professor Fábio, em uma das aulas do $1^{\circ}$ ano, propôs que os estudantes respondessem às seguintes questões: "1- Quem é o filósofo? 2- O que é a inteligência? 3- Qual o papel da filosofia? 4- Quais são as características do pensamento filosófico?" (Diário de campo). Os estudantes Paula, Sérgio, Roberto e Pablo fizeram uma síntese do texto didático, respondendo às questões propostas do seguinte modo:

1- O filósofo é um explorador incansável que não se limita e não se acha incapaz. Reflete sobre o que vê, investiga os fatos e vive como pensa. 2- É uma faculdade que permite enfrentar problemas, inventar coisas e soluções, aprender a pensar criticamente e refere-se ao juízo que é a capacidade de diferenciar o verdadeiro do falso. 3- Analisar, ensinar a usar a inteligência, ser e agir, nominar as coisas e produzir um agir racional buscando respostas. 4- Refletir, problematizar, investigar, questionar, fazer crítica. Trata-se de um pensamento radical (Diário de campo)

$\mathrm{Na}$ concepção dos estudantes, o filósofo é aquele que busca pensar racionalmente, argumentando, justificando e provando suas afirmações, a fim de possibilitar aos outros a compreensão, a comprovação e a aceitação daquilo que foi dito. Ademais, o tema da "angústia filosófica" havia sido introduzido por Fábio em aula anterior com a mesma turma, a fim de tornar mais significativo, para os estudantes, como é o modo de viver daqueles que buscam a atitude filosófica em suas vidas. Pela introdução de um poema ${ }^{11}$ nessa exposição, o professor criou uma interação entre filosofia e literatura, propiciando aos estudantes uma experiência estética e o aprofundamento da compreensão sobre esse modo filosófico de viver.

Perdi-me muitas vezes pelo mar, com o ouvido cheio de flores recémcortadas, com a língua cheia de amor e de agonia. Muitas vezes perdi-me pelo mar, como me perco no coração de alguns meninos. Não há noite em que, ao dar um beijo, não sinta o sorriso das pessoas sem rosto, nem há ninguém que, ao tocar um recém-nascido, olvide as imóveis caveiras de cavalo. Porque as rosas buscam em frente uma dura paisagem de osso e as mãos do homem não têm mais sentido que imitar as raízes sob a terra.

${ }^{11}$ LORCA, Frederico García. Gazel da Fuga.

SILVA, Gilson Malta da. O ensino de filosofia nas perspectivas inter e transdisciplinar: a problemática do conhecimento. Griot : Revista de Filosofia, Amargosa, Bahia, v.16, n.2, p.398-422, dezembro/2017. 
Como me perco no coração de alguns meninos, perdi-me muitas vezes pelo mar. Ignorante da água vou buscando uma morte de luz que me consuma. (Diário de campo)

\section{Pensamento e conhecimento}

As relações entre pensamento e conhecimento constavam em Marina assim como foi também abordada na mediação do professor Fábio em sala de aula. A princípio, o ato de pensar foi concebido pelo docente como "abstração, ou seja, trazer para dentro" (Diário de campo). Utilizando-se de uma linguagem metafórica em sua explicação, o docente expressou-se do seguinte modo: 'assim como uma esponja absorve a água, a mente humana "absorve" e "incorpora" as coisas" (Idem). Acrescentou ainda que, considera haver um certo descompasso entre o pensar e o expressar, seja na escrita, seja na fala, e nem sempre "o ser humano consegue exteriorizar o que pensa e sente de uma maneira adequada para ser compreendido pelos outros" (Idem). Essa caracterização do pensamento não constava em Marina (2010).

O livro didático define o pensamento ou o raciocínio como criar ideias. "É operar mentalmente valendo-se do conhecimento e adotando regras, métodos e critérios adequados" (MARINA, 2010, p. 10). Segundo o autor, o pensamento consiste numa atividade que se caracteriza pela formação de juízos e pela utilização de operações mentais pelas quais comparamos, relacionamos, deduzimos e inferimos. Os seres humanos organizam informações, ideias e conhecimentos e, assim realizam um pensamento mais consistente, a fim de alcançar uma meta ou um objetivo proposto. Para o autor do livro didático, pensar é raciocinar, mas, para Fabio, não é só isso. Ele amplia o sentido dado pelo autor e chama a atenção dos estudantes para perceberem que "pensar é refletir e tal atividade consiste num processo mais amplo que apenas raciocinar" (Diário de campo).

Além do mais, o docente destacou que raciocinar pode ser considerado também como "a passagem do senso comum para o senso crítico" (Idem). O senso comum caracteriza-se como "uma postura de aceitação daquilo que é dito e vivido sem maiores investigações" (Idem). O senso crítico seria "a busca de um método para distinguir o verdadeiro e o falso" (Idem). Esse método iniciaria com a busca de dados, informações e conhecimentos que poderiam ser utilizados para um maior esclarecimento da problemática investigada. Segundo os estudantes Fernanda e Sérgio, “alcançar esse pensamento crítico é algo um tanto incerto, pois as próprias informações que recebemos e selecionamos podem estar deturpadas em alguns aspectos" (Idem). Eles consideram que a obtenção de um dado, a observação de um fenômeno ou a experiência cotidiana de ter uma impressão sobre alguma coisa na vida não significa obter uma informação verdadeira que fundamentará um conhecimento verdadeiro. Podemos criar juízos falsos a respeito de muitas situações.

\section{O pensamento, as perguntas, os problemas e os saberes}

Por meio da leitura e explicação de três fragmentos de textos apresentados no livro didático, (Quadro 2, b.1, b.2, b.3), o professor procurou evidenciar a importância das perguntas para a criação de novos conhecimentos e, assim, iniciou 
uma comunicação entre filosofia, física e biologia. $\mathrm{O}$ primeiro fragmento refere-se às conquistas da física moderna e às interrogações que os cientistas cogitam para fazer o conhecimento avançar. $\mathrm{O}$ segundo fragmento faz menção aos mecanismos instintivos que os animais dispõem para solucionarem os problemas relativos à sobrevivência. Um terceiro trecho apresentado pelo autor do livro didático apresenta o modo como Fleming investigou um problema biológico e acabou por descobrir a penicilina. No entanto, não houve maiores explicitações sobre as mencionadas conquistas da física e nem a respeito dos conteúdos biológicos aludidos no segundo e terceiro fragmentos. Por isso, a tentativa de elaboração de uma reflexão filosófica interdisciplinar não se desenvolveu satisfatoriamente.

Ademais, Marina denota que todas as áreas do conhecimento defrontam-se com diferentes perguntas, problemas e engendram distintos critérios e modos específicos de pensar em cada um desses problemas. No entanto, por mais que as informações, os objetivos e os métodos sejam divergentes, as operações realizadas para concretizar a atividade do pensar são comuns. Por isso, usamos a mesma inteligência para pensar questões muito distintas (Quadro 2, b.4 e b.5). Também, com o objetivo de explicitar os aspectos comuns ao pensamento, o professor Fábio utilizou o texto do autor do livro didático que apresentou uma comparação entre os seguintes modos de pensar: o poético e o matemático (Quadro 2, c). Nesse excerto de texto o referido autor ainda destaca que outra característica do saber filosófico consiste em "relacionar conhecimentos ou atividades diversas" (Idem). Com a explicitação desse conteúdo, o docente relacionou a matemática com a literatura, no caso em questão, aspectos dos pensamentos matemático e poético.

Além disso, em consonância com o autor do livro didático, o professor Fábio destacou que, "a questão sobre - o que podemos esperar? - relaciona-se à busca pelo sentido da vida e à relação entre fé e razão" (Diário de campo). Acrescentou ainda que, nessas reflexões, muitos filósofos tentaram demonstrar a existência de Deus por argumentos mais racionais, como Santo Tomás, ou mais vitais, como Kierkegaard. Nos dois tipos de argumentos os filósofos especularam sobre a possibilidade de uma vida após a morte, ou, então, se a vida humana teria algum sentido transcendental e se haveria algum sentido único para a realidade. Em seguida à explanação do docente, os estudantes Paula, Sérgio, Roberto e Pablo apresentaram um trabalho sobre esse tema e expuseram as principais ideias selecionadas no livro didático da seguinte maneira:

\footnotetext{
Enquanto a ciência procura encontrar explicações empíricas sobre a origem do universo, a filosofia procura alguma explicação lógica e razoável sobre tais questões, pois o ser humano, por ser consciente de sua própria finitude, necessita encontrar um sentido para sua existência (Diário de campo)
}

Outrossim, o autor do livro didático elucida que o saber filosófico compreende o homem como um ser biológico e cultural, ou seja, sujeito às mesmas leis naturais que agem sobre todos os animais, porém com características exclusivas que o distingue destes. Acrescentou ainda que, na história da filosofia, os filósofos constituíram o campo da antropologia filosófica, com a contribuição de distintas disciplinas científicas, diversas teorias e concepções acerca do ser humano e da 
humanidade (Quadro 3, c). Considerando o objetivo interdisciplinar desse ensino de filosofia, pode-se salientar que, essa questão da constituição da antropologia filosófica a partir do aporte de teorias de outras disciplinas não foi significativamente explicitada pelo docente.

Além do mais, num espaço do material didático intitulado "Aprender a ler filosofia", Marina (2010) relaciona o significado da palavra "compreender" com um conto de Liev Tolstói com o objetivo de problematizar com os estudantes a idéia de "compreensão" através do processo de compreensão de um texto. Tratou-se de uma proposta de atividade com grande potencial para relacionar filosofia e literatura, pois para elucidar uma temática filosófica o autor do livro didático utilizou-se de um texto literário e explicitou os recursos nele utilizados (Quadro 3; d). Esse tema não foi abordado na mediação do docente.

Após essa descrição e interpretação dos modos como a temática do conhecimento foi problematizada nesse ensino de filosofia e, considerando as pretensões inter e transdisciplinares do referido ensino, passa-se agora a apresentar sinteticamente a abordagem da problemática do conhecimento a partir do paradigma da complexidade e da compreensão transdisciplinar de realidade. Segundo Morin (2005b) a noção de conhecimento comporta diversidade e multiplicidade. Sendo assim, "o conhecimento é, portanto, um fenômeno multidimensional, de maneira inseparável, simultaneamente físico, biológico, cerebral, mental, psicológico, cultural, social (MORIN, 2005b, p. 18). Essa definição pressupõe que todo acontecimento cognitivo para existir necessita da conexão de processos elétricos, químicos, fisiológicos, existenciais, psicológicos, culturais, lógicos, individuais, coletivos, dentre outros.

Para mais, Morin (2005b) evidencia o núcleo do pensamento complexo destacando três princípios de inteligibilidade ou operadores: o dialógico, o recursivo e o hologramático ${ }^{12}$; operadores que o pesquisador considera como os mais convenientes para estudar os fenômenos complexos da realidade. Ainda, o autor explicita a necessidade de uma reforma do pensamento na educação formal, seja no nível superior (âmbitos da pesquisa científica, filosófica e do ensino), seja no nível básico. (MORIN, 2010). Um dos aspectos propostos para essa reforma é a organização de um conhecimento pertinente, ou seja, aquele conhecimento cujo ensino leva em consideração "o contexto, o global (a relação todo/parte), o

12 Princípio dialógico: "trata-se da associação complexa (complementar/concorrente/antagônica) de instâncias necessárias em conjunto à existência, ao funcionamento e ao desenvolvimento de um fenômeno organizado" (MORIN, 2005b, p. 110). Por exemplo: "[...] necessidade de conceber partículas físicas como corpúsculos e como ondas, ao mesmo tempo" (MORIN, 2010, p. 96). Princípio recursivo: "Trata-se de um processo em que os efeitos ou produtos são, ao mesmo tempo, causadores e produtores no próprio processo, sendo os estados finais necessários à geração dos estados iniciais" (MORIN, 2005b, p. 113). Por exemplo: “[...] nós, indivíduos, somos os produtos de um sistema de reprodução que vem do início dos tempos, mas esse sistema não pode se reproduzir se nós mesmos não nos tornarmos produtores com o acasalamento" (MORIN, 2010, p. 95). Princípio hologramático: “[...] o todo está de certa maneira incluído (gravado) na parte que está incluída no todo" (MORIN, 2005b, p. 114). Por exemplo: “[...] cada célula é uma parte de um todo - o organismo global - , mas também o todo está na parte: a totalidade do patrimônio genético está presente em cada célula individual; a sociedade está presente em cada indivíduo, enquanto todo, através de sua linguagem, sua cultura, suas normas" (MORIN, 2010, p. 94). Para maiores esclarecimentos sobre os princípios da complexidade, conferir: Morin (2005d, p. 211-257; 2010, p. 92-97). 
multidimensional, o complexo" (MORIN, 2000, p. 35). Nesse sentido, o professor de filosofia poderia mediar o ensino construindo reflexões que se estendessem "aos conhecimentos científicos, bem como à literatura e à poesia, alimentando-se ao mesmo tempo de ciência [...]" (MORIN, 2010, p. 23).

\section{Considerações finais}

À guisa de conclusão, retomamos sinteticamente, a seguir, algumas considerações apresentadas na análise e interpretação dos dados. Em primeiro lugar, à época das investigações pode-se constatar que o Colégio ainda mantinha uma organização curricular tradicional e não possuía um seu planejamento educacional baseado na concepção transdisciplinar de realidade. Também não havia sido inserido como conteúdo curricular as características dessa nova visão de mundo. Todavia as articulações disciplinares efetuadas pelo docente na problematização do conhecimento envolveram áreas ou disciplinas não vizinhas; tais como: física, psicologia, literatura, biologia, matemática e filosofia.

Em seguida, é preciso salientar que a mediação docente estava, de certo modo, em consonância com as orientações governamentais sobre o ensino de filosofia; principalmente no que se refere à utilização de textos científicos e literários, teorias e conceitos de outros campos disciplinares não apenas como recursos motivadores, mas como meios para construir uma problematização filosófica. Ressalta-se aqui a escolha pelo docente de um material didático que possibilitava pensar os problemas filosóficos inserindo contribuições de outros campos de conhecimento e das artes. Por esse ângulo, o professor Fábio desenvolveu, até certo ponto, um aspecto do conceito de interdisciplinaridade escolar, a saber: problematizar um determinado fenômeno, a partir de diferentes pontos de vista, pela inserção no debate de conhecimentos de várias disciplinas. Contudo, como o docente não planejou aulas em conjunto com outros professores, os conteúdos de outras disciplinas citados em sua exposição não foram aprofundados suficientemente a fim de produzir articulações mais relevantes entre a filosofia e os outros campos disciplinares.

Além disso, outro aspecto a evidenciar refere-se à concretização do princípio da contextualização nas aulas de filosofia. Decerto que a mediação do docente permitia um espaço para problematizações e debates entre os sujeitos participantes. Entretanto, a maioria dos temas abordados nesse ensino sobre o conhecimento foram escolhidos pelo docente sem a participação dos estudantes. Sendo assim, pode-se afirmar que a contextualização não se concretizou em seu aspecto fundamental: organizar conhecimentos escolares a partir das experiências (vivências extraescolares e escolares). Ademais, é pertinente ainda salientar que os documentos governamentais carecem de uma elaboração conceitual da transdisciplinaridade escolar e de melhores explicitações de suas características a fim de colaborar de modo mais efetivo para a implementação dessa nova visão educacional nas escolas.

Por fim, em vista dos argumentos apresentados, pode-se considerar que esse ensino de filosofia sobre a temática do conhecimento não se concretizou numa perspectiva inter ou transdisciplinar, mas como uma vivência (experiência) de multidisciplinaridade escolar "modesta". 


\section{Referências bibliográficas}

BARDIN, Laurence. Análise de conteúdo. Lisboa: Edições 70, 1988.

BRASIL. Lei $n^{\circ}$ 9394, de 20 de dezembro de 1996. Estabelece as Diretrizes e Bases da Educação Nacional. Brasília, 1996. Disponível em: < https://www.planalto.gov.br/ccivil_03/Leis/L9394.htm>. Acesso em: 28 out. 2016.

BRASIL. Ministério da Educação. Conselho Nacional de Educação. Câmara de Educação Básica. Resolução $\mathrm{n}^{\circ} 3$ de 26 de junho de 1998. Institui as Diretrizes Curriculares Nacionais para o Ensino Médio. Brasília, 1998. In: BRASIL. Ministério da Educação. Secretaria de Educação Média e Tecnológica. Parâmetros curriculares nacionais para o ensino médio. (Parte I - Bases Legais). Brasília, 1999a. Disponível em: <http://portal.mec.gov.br>. Acesso em: 30 mai. 2016.

BRASIL. Ministério da Educação. Secretaria de Educação Básica. Orientações curriculares para o ensino médio: ciências humanas e suas tecnologias. Brasília, 2006. Disponível em: <http://portal.mec.gov.br>. Acesso em: 06 out. 2016.

BRASIL. Ministério da Educação. Secretaria de Educação Básica. Secretaria de Educação Continuada, Alfabetização e Inclusão. Secretaria de Educação Profissional e Tecnológica. Câmara Nacional de Educação Básica. Resolução n ${ }^{\circ} 2$ de 30 de janeiro de 2012. Institui as Diretrizes Curriculares Nacionais para o Ensino Médio. Brasília, 2012. In: BRASIL. Ministério da Educação. Secretaria de Educação Básica. Secretaria de Educação Continuada, Alfabetização e Inclusão. Secretaria de Educação Profissional e Tecnológica. Diretrizes Curriculares Nacionais da Educação Básica. Brasília, 2013. Disponível em: <http://portal.mec.gov.br>. Acesso em: 30 mai. 2016.

BRASIL. Ministério da Educação. Secretaria de Educação Média e Tecnológica. Parâmetros curriculares nacionais para o ensino médio: orientações educacionais complementares aos parâmetros curriculares nacionais. Brasília, 1999b. Disponível em: <http://portal.mec.gov.br>. Acesso em: 09 out. 2016.

CARVALHO, Edgard de Assis. Saberes complexos e educação transdisciplinar. Educar, Curitiba, v. 32, n. 1, p. 17-27, 2008.

CHERVEL, A. História das disciplinas escolares: reflexões sobre um campo de pesquisa. Teoria e Educação, 2, 1990.

COLÓQUIO DE VENEZA, 1986, Veneza. A Ciência Diante das Fronteiras do Conhecimento. Veneza: UNESCO, 1986. 2 p. (Declaração). Disponível em: < http://www.ufrrj.br/leptrans/arquivos/Declaracao_Veneza_1986>. Acesso em: 15 fev. 2012.

CONFERÊNCIA INTERNACIONAL DE ZURIQUE, 2000, Zurique. Conferência Transdisciplinar Internacional. Zurique, 2000. 3 p. (Declaração). Disponível em: < http://www.cetrans.com.br/textos/documentos/declaracao-zurique-2000.pdf>.

Acesso em: 15 fev. 2012.

CONGRESSO DE PARIS, 1991, Paris. Ciência e Tradição: Perspectivas Transdisciplinares para o século XXI. Paris: UNESCO, 1991. 2 p. (Comunicado Final). Disponível em: http://www.ufrrj.br/leptrans/arquivos/Congresso_Ciencia_Tradicao_1991.pdf > . Acesso em: 15 fev. 2012. 
CONGRESSO INTERNACIONAL DE LOCARNO, 1., 1997, Locarno. Que universidade para o amanhã? Em busca de uma evolução transdisciplinar da universidade. Locarno: CIRET-UNESCO, 1997. 11 p. (projeto). Disponível em: < http://ciret-transdisciplinarity.org/locarno/locapor4. php>. Acesso em: 15 fev. 2012. CONGRESSO MUNDIAL DE ARRÁBIDA, 1., 1994, Arrábida. Primeiro Congresso Mundial da Transdisciplinaridade. Arrábida: CIRET-UNESCO, 1994. 3 p. (Carta da Transdisciplinaridade). Disponível em: < http://cetrans.com.br/wpcontent/uploads/2014/09/carta-da-transdisciplinaridadel.pdf $>$. Acesso em: 15 fev. 2012.

COTIM, Gilberto. Fundamentos da filosofia: história e grandes temas. São Paulo: Saraiva, 2010.

CNSL. Colégio Nossa Senhora de Lourdes. Projeto Político-Pedagógico. Lavras: CNSL, 2012.

DELEUZE, G.; GUATTARI, F. O que é a filosofia? Rio de Janeiro: Editora 34, 1992.

DOMINGUES, Ivan. Conhecimento e transdisciplinariedade. Belo Horizonte: UFMG, 2004.

. Conhecimento e transdisciplinariedade II: aspectos metodológicos.

Belo Horizonte: UFMG, 2005.

FARIAS, Francisco R. Sobre o conceito de estresse. Arquivo Brasileiro de Psicologia, Rio de Janeiro, 38(4), p. 97-105, out./dez. 1985. Disponível em: < http://bibliotecadigital.fgv.br/ojs/index. php/abp/article/view/19342/18084>. Acesso em: 14 fev.2012.

GALLO, Sílvio. Conhecimento, transversalidade e educação: para além da interdisciplinaridade. 2006.2010 Disponível em: <http://www.cedap.assis.unesp.br/cantolibertario>. Acesso em: 3 out. 2010. . Filosofia e seu ensino: conceito e transversalidade. In: SILVEIRA, J.

T. René; GOTO, Roberto (Org.). Filosofia no ensino médio: temas problemas e propostas. São Paulo: Loyola, 2007. p. 15-36.

GALLO, Sílvio et al. O ensino da filosofia no Brasil: um mapa das condições atuais. Caderno Cedes, Campinas, v. 24, n. 64, p. 257-284, set./dez. 2004. Disponível em:<http://www.cedap.assis.unesp.br/cantolibertario>. Acesso em: 19 nov. 2016.

GALLO, Sílvio; KOHAN, Walter Omar (Org.). Filosofia no ensino médio. Petrópolis: Vozes, 2000.

JAPIASSU, Hilton. Interdisciplinaridade e patologia do saber. Rio de Janeiro: Imago, 1976.

LOPES, A. C. Políticas curriculares: continuidade ou mudança de rumos. Revista Brasileira de Educação. Rio de Janeiro, nº 26, p. 109 - 118, maio/jun/jul/ago, 2004.

MARCONI, Marina de Andrade; LAKATOS, Eva Maria. Fundamentos da metodologia científica. São Paulo: Atlas, 2010.

MARINA, José Antônio. Filosofia e cidadania. São Paulo: Ed. SM, 2010.

MINAS GERAIS. Secretaria de Estado de Educação. Filosofia: proposta curricular: ensino médio. Belo Horizonte, 2006. Disponível em: $<$ http://crv.educacao.mg.gov.br>. Acesso em: 30 dez. 2012.

MINAYO, M.C.S. O desafio do conhecimento: pesquisa qualitativa em saúde. 7. ed. São Paulo: Hucitec, 2000. 
MORIN, Edgar. A natureza da natureza. Porto Alegre: Sulina, 2008 a. . As ideias. Porto Alegre: Sulina, $2005 \mathrm{~d}$. . A vida da vida. Porto Alegre: Sulina, 2005c. . Cabeça bem-feita. Rio de Janeiro: Bertrand Brasil, 2010. . Ciência com consciência. Rio de Janeiro: Bertrand Brasil, 2005 a. O conhecimento do conhecimento. Porto Alegre: Sulina, 2005b. . Os Sete saberes necessários à educação do futuro. São Paulo: Cortez,

2000.

NICOLESCU, Basarab. Contradição, lógica do terceiro incluído e níveis de realidade. Disponível em: <http://www.cetrans.com.br>. Acesso em: 16 jan. 2012a.

Definition of transdisciplinarity. Disponível em: <http://www.interdisciplines.org/interdisciplinatity/papers>. Acesso em: 9 ago. 2012 b.

NICOLESCU, B. O manifesto da Transdisciplinaridade. São Paulo: Triom, 1999.

NICOLESCU, Basarab; BADESCU, Horia (Org.). Stéphane Lupasco: o homem e a obra. São Paulo: Triom, 2001.

PETRAGLIA, Izabel. A educação e a complexidade do ser e do saber. Petrópolis: Vozes, 2010.

SANTOS, Akiko. Complexidade e transdisciplinaridade em educação: cinco princípios para resgatar o elo perdido. Revista Brasileira de Educação, São Paulo, v. 13, n. 37, jan./abr. 2008. Disponível em: <http://www.scielo.br/pdf/rbedu/v13n37/07.pdf>. Acesso em: 16 out. 2011.

SILVA, Daniel José da. O paradigma transdisciplinar: uma perspectiva metodológica para a pesquisa ambiental, 1999. Disponível em: <http://www.cetrans.com.br>. Acesso em: 16 jan. 2012.

SOMMERMAN, Américo. Inter ou transdisciplinaridade? Da fragmentação disciplinar ao novo diálogo entre os saberes. São Paulo: Paulus, 2006.

ZIBAS, D. M.L. A reforma do ensino médio nos anos de 1990: o parto da montanha e as novas perspectivas. Revista Brasileira de Educação, Rio de Janeiro, Fundação Carlos Chagas, n.28, p. 24-36, jan./abr. 2005. Disponível em: < http://www.scielo.br/pdf/rbedu/n28/a03n28.pdf >.Acesso em: 02 jul.2016.

WEIL, P.; AMBRÓSIO, U. d'; CREMA, R. Rumo a nova transdisciplinaridade: sistemas abertos de conhecimento. São Paulo: Summus, 1993.

Autor(a) para correspondência: Gilson Malta da Silva, Universidade Federal de São João del-Rei, Praça Frei Orlando, 170, Centro, CEP 36307-352, São João del-Rei - MG, Brasil. fidalgogi@hotmail.com 